\title{
Basic microsurgery training. Comments and proposal
}

\author{
Treinamento básico em microcirurgia. Comentários e proposta
}

\author{
Paulo Ney Aguiar Martins ${ }^{1}$, Edna Frasson de Souza Montero ${ }^{2}$ \\ 1. MD, PhD, Department of Surgery, Division of Transplant Surgery, Brigham and Women's Hospital, Harvard Medical School, Boston, U.S.A. \\ 2. MD, PhD, Affiliate Professor of the Department of Surgery, Federal University of São Paulo (UNIFESP), São Paulo, Brazil.
}

\begin{abstract}
Microsurgical techniques have been applied in many surgical specialties and have also a broad application in surgical research. It demands high technical skills and continued training. The microsurgical training is lengthy, very expensive and demands high commitment. The microsurgical skills should be first mastered in the lab and only then applied in the clinic. Here, we propose a model of a training course in microsurgery. We also suggest that surgical societies involved with microsurgery promote training courses on a regular basis.
\end{abstract}

Key words: Microsurgery. Teaching. Education. Motor Skills.

\section{RESUMO}

Microcirurgia tornou-se uma técnica aplicável em uma série de especialidades cirúrgicas e em pesquisa experimental. Microcirurgia exige alta qualidade técnica e treinamento contínuo. No Brasil, existe grande carência de microcirurgiões devido aos custos envolvidos no treinamento e na escassez de serviços que ofereçam treinamento especializado. $O$ treinamento em microcirurgia é longo, caro e exige alto grau de dedicação. O completo domínio das técnicas de microcirurgia deve ser obtido primeiro no laboratório antes de ser empregada na prática clínica. Nesse artigo, propõe-se um modelo de curso teórico-prático em microcirurgia. Também sugere-se que sociedades de especialidades cirúrgicas mais ligadas à microcirurgia fomentem a capacitação de profissionais em microcirurgia através da realização de cursos básicos em microcirurgia.

Descritores: Microcirurgia. Ensino. Educação. Destreza Motora.

\section{Introduction}

Microsurgery can be applied in almost every surgical specialty and has become part of surgical training in institutions of excellence ${ }^{1-3}$. Common examples of the use of these techniques are: implantation of members or digits after traumatic amputations, vascularized skin grafts in reconstructive plastic surgery, recanalization of the deferent vas and fallopian tubes after sterilization procedures, reconstruction of vessels in transplantation surgery, neurological, pediatric, orthopedic, endo-odontologic, ophthalmologic, and otorrionolaringologic surgeries. Even the general surgeon needs, sometimes, microsurgical techniques to perform biliodigestive anastomosis, biliar duct anastomosis or for uncomplicated vascular reconstructions ${ }^{4}$. The microvascular training promotes also the ability in conventional surgery once one can train dissection of delicate structures; and the ability in videoassisted surgery, as microsurgery also uses optical instruments. Besides that, microsurgical techniques are very useful for surgical research, since rodents, for ethical, financial and practical reasons became the favorite experimental model ${ }^{1,5}$. In Brazil, there is a great demand of microsurgeons. In the majority of federal states there is no center of training and no regular microsurgical course. The existence of a local or regional microsurgical center has a particular importance in cases of emergencies, such as traumatic amputations, situation in which the time required for successful implantation is short, and the transport to a distant reference center is not feasible. One of the principal obstacles for the training in microsurgery is the cost of training. There are few laboratories, and the optic equipment, instruments and sutures are very expensive ${ }^{6}$. Some surgical societies in Brazil begin to show interest to offer microsurgical training on a regular basis. For example, the Brazilian Transplantation Society (ABTO) has supported the realization of a microsurgery course during its annual meeting in 2005 (Figure 1). Other surgical societies could also offer or support regular courses on basic techniques to increase the awareness of the importance of microsurgery and increase the number of microsurgeons. 


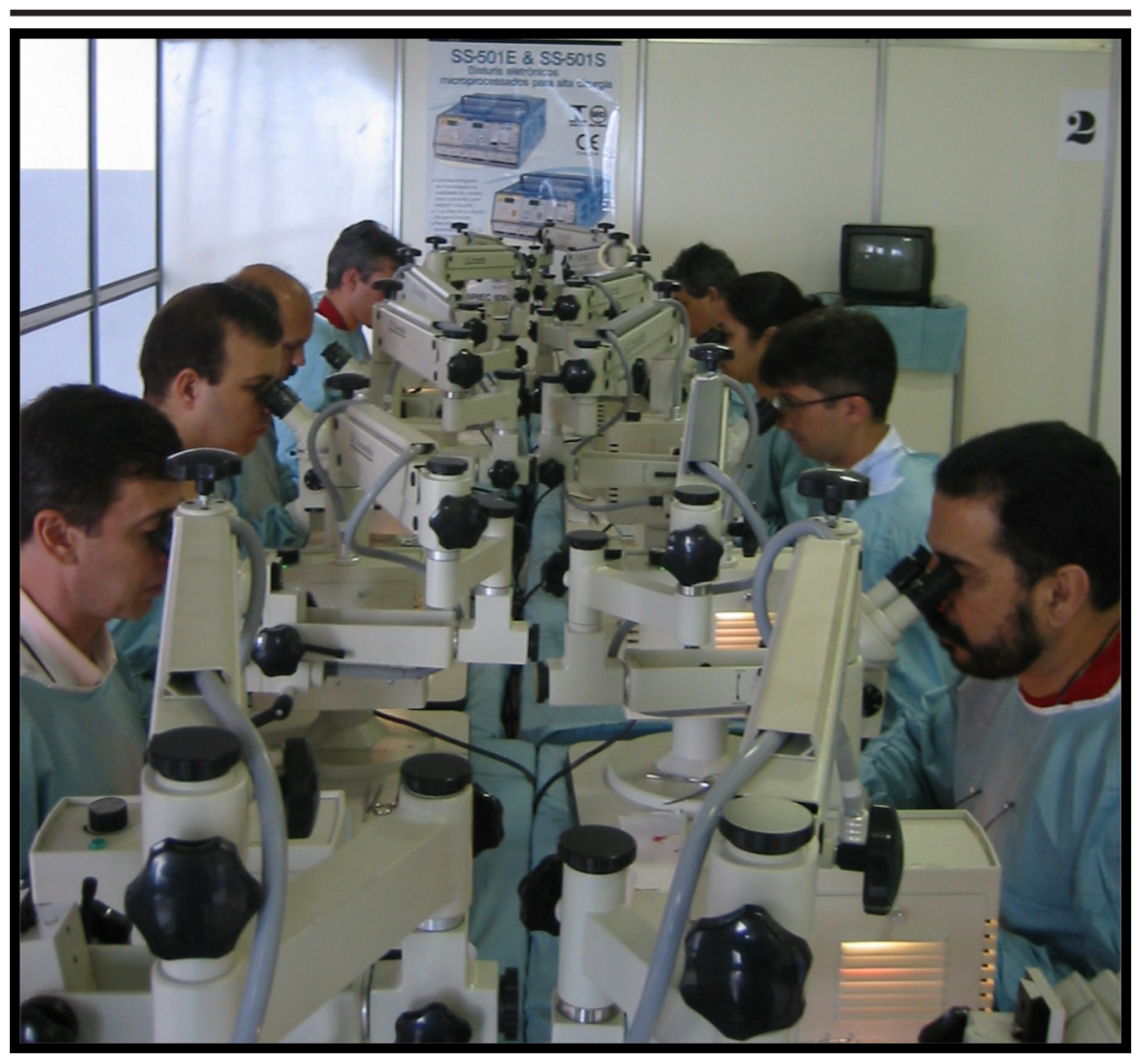

FIGURE 1 - Microsurgery course performed during the IX Congress of the Brazilian Transplant Society and IV Potuguese-Brazilian Transplant Congress, promoted by the Brazilian Transplant Society-ABTO (Salvador July of 2005)

details and tricks and the amount of information is too much for being learned in just two days. In a survey done in USA, $81 \%$ of the microsurgical basic courses have 40 hours divided in ten days ${ }^{8}$. We also agree that a basic microsurgery course should be intensive with fours hours a day over 2 weeks (totalizing 40 hours). The amount of theoric lessons should not be more than 8 hours. Theoric lessons should first address questions on handling and adjustments of loupes and microscopes, description and handling of microinstruments, basic techniques of dissection and suture, vascular anastomosis, and anesthesia for rodents. For handson training lessons, to assure better learning, the number of trainees should preferably be not more than 3 for each instructor. The level of difficulty of exercises should be slowly progressive to assure better adaptation with the microscope and instruments. During the first days it is advised to avoid living animals for training. First, because during the first phase of training it is not important to work on "real" situation, second it is more ethical

\section{The microsurgery training course}

The ability in microsurgery should only be applied in the clinic after a long training period in the lab. Mastering the techniques of microsurgery is a long and difficult process. It demands high manual skills, patience, dedication and continued training. Even a skillful surgeon is not able to perform microsurgery without specialized training. The ability in microsurgery should be gained gradually. The microsurgical course includes theoric and practical lessons and is divided in two parts: basic and advanced. Independent of the surgical specialty of the trainee it is essential to learn: basic techniques of anesthesia and surgery in rodents, microdissection and suture (including microanastomosis). After mastering the basic techniques, the course can be directed towards particular procedures of different specialties ${ }^{7}$. The advanced course should be directed to trainees that already master basic techniques and intend to train on their specialized clinical area or do research projects involving specific procedures. It is clear that the learning process is faster and better when the training is intensive and continuous instead of doing sporadically over a long period. There are some courses in USA that offer basic training in microsurgery for 7 hours/ day during 2 consecutive days, what is disadvantageous once it is extreme short and extenuating. For a beginner, after the first working hours on a surgical microscope, it is common the occurrence of headaches, muscular pain and loss of concentration. Besides that, microsurgery is full of once many lives can be saved, and third the training costs are significantly reduced. Many training centers use a latex board (piece of a surgical glove attached on a board) until a minimum of suture quality is achieved. Afterwards, we recommend the use of a "PVC rat ${ }^{\circledR}$ " model, or self-made "latex tube model" 10 to learn how to perform circular sutures (anastomosis). These alternative models have as disadvantages the fact of not offering structures of similar consistence with biologic tissues, and not allowing the training of dissection techniques. Very useful is the use of animal cadavers, which were sacrificed at the end of a research project or during the training of more advanced trainees. These animals can be stored for a long time (up to 5 days) in a refrigerator, particularly if the bowels are removed, without losing their natural consistence after thawing. When the trainee learns the technique of microanastomosis in animal cadavers, he or she can begin operating on living animals. To optimize the use of living animals, many microanastomoses can be performed on the same animal at the same session before sacrificing it. Basic training does not mean that after 2 weeks of training in the lab the trainee will be apt to perform complex tasks or to use it in the clinical seetings ${ }^{11}$. Because of the very delicate structures and the high probability of vascular spasms, the results of microsurgery are, in the majority of situations, of the "all or nothing" kind. In most cases, the failure in microsurgery is not reparable, and the consequences are tissue congestion, ischemia and necrosis. Thus, it is strongly recommended that the trainee performs microanastomoses 
in the clinic only after obtaining a success rate, using vessels of similar caliber in the lab, superior than $80 \%$ of patency. The same principle is applied to begin a research project, situation in which standardization of procedures and reproducibility of results is essential to reach statistical significance and validate results. Besides technical quality, the time required to perform the anastomoses need to be considered when implantation of organs and tissues is in question, because the isquemia/reperfusion injury is increased with time. So, to be considered apt, the trainee needs not only to achieve a minimum level of quality but need to be fast. The learning curve in microsurgery is slow and is very trainee-dependent. Not every microsurgical trainee will become a successful microsurgeon even after intensive training. The major problems are impatience, incoordination and tremor. The time in the lab is important to correct these problems or to convince oneself that he or she is not able to perform microsurgery in the clinic. The transition between experimental and clinical microsurgery is not easy and automatic. The clinical success depends not only on technical abilities, but on precise intraoperative judgment and meticulous post-operative care, factors that are obtained only with long clinical experience. After manual skills are obtained, the microsurgical training should combine clinical practice with experimental exercises in the lab. The microsurgical training should be continuous, not only to keep manual abilities, but also to learn and develop new techniques.

\section{References}

1. Martins PNA. The importance of experimental microsurgery for transplantation [Port]. Acta Cir Bras. 2003; 18:59-61.

2. Di Cataldo AD, Trombatore G, Ciraldo R, Rodolico M, Sorbello M, Destri GL. Experimental research and surgery: why, how, and when? Microsurgery. 2001; 21:118-20.
3. Kizilisik A, Sebayel MA, Ramirez CB. Microsurgery training for transplantation purposes. Transplant Proc. 1998; 30:3016.

4. Di Cataldo AD, Destri GL, Trombatore G, Papillo B, Rocalbuto A, Puleo S. Usefulness of microsurgery in the training of the general surgeon. Microsurgery. 1998; 18:446-8.

5. Hoyt RF, Clevenger RR, McGehee JA. Introduction to microsurgery: an emerging discipline in biomedical research. Lab Anim. 2001; 30:26-35.

6. Webster R, Ely PB. Treinamento em microcirurgia vascular: é economicamente viável? Acta Cir Bras. 2002; 17: 194-7.

7. Miko I, Brath E, Furka I. Basic teaching in microsurgery. Microsurgery. 2001; 21:121-3.

8. Montero EFS, Simão AFL. Chagas Neto FA, Barroso TA. Microsurgery training using a PVC rat model. Book of abstracts of the $8^{\text {th }}$ Congress of the International Society for Experimental Microsurgery; 2006 July 16-19; Montreal, CA.

9. Goossens DP, Gruel SM, Rao VK. A survey of microsurgery training in the United States. Microsurgery. 1990; 11:2-4.

10. Pessoa BBGP, Pessoa SGP. Treinamento em microanastomoses utilizando tubos de látex. Acta Cir Bras. 2002; 17(2):143-6.

11. Yasargil MG. From the microsurgical laboratory to the operation theatre. Acta Neurochir. 2005; 147: 465-8.

\section{Acknowledgments}

Associação Brasileira de Transplantes (ABTO), DF Vasconcellos S.A., Roca-Instrumentos Microcirúrgicos, and Instituto do PVC to help us on our first basic microsurgery course at the Congress of the Brazilian Transplant Society.

\section{Correspondence:}

Dr. Paulo Ney Aguiar Martins

221 Longwood Ave, Rm 309

Harvard Medical School

Boston, Ma. 02115

U.S.A.
Conflict of interest: none Financial source: none

Received: August 11, 2006

Review: September 19, 2006

Accepted: October 23, 2006

\section{How to cite this article:}

Martins PNA, Montero EFS. Basic microsurgery training: comments and proposal. Acta Cir Bras. [serial on the Internet] 2007 Jan-Feb;22(1). Available from URL: http://www.scielo.br/acb. 